\title{
The End of Reparations Talk: Reparations in an Obama World
}

\author{
Kevin Outterson*
}

\section{INTRODUCTION}

Several years ago, I wrote an article on reparations for disparities in Black health in the United States. ${ }^{1}$ The world did little note nor long remember what I said in that article. But, the University of Kansas Law Review has rescued my thoughts from obscurity, at least temporarily.

My thesis proceeded in three parts: (1) U.S. disparities in Black health are dangerous and persistent; ${ }^{2}$ (2) Black health disparities cannot be viewed in isolation from our history of slavery, racism, and legal segregation; ${ }^{3}$ and (3) superficial remedial efforts are not likely to be

\footnotetext{
* Associate Professor of Law, Boston University School of Law. My thanks are again offered to my colleague andre douglas pond cummings at the West Virginia University College of Law for his thoughtful comments.

1. Kevin Outterson, Tragedy and Remedy: Reparations for Disparities in Black Health, 9 DePaul J. Health CARE L. 735 (2005) [hereinafter Outterson, Tragedy \& Remedy].

2. InSt. OF MED. OF THE NAT'L ACAD., UNEQUAL TREATMENT: CONFRONTING RACIAL AND ETHNIC DisParities IN HeAlth CARE 29-30 (Brian D. Smedley et al. eds., 2003).

3. The legal literature on racial disparities in health is significant. See, e.g., Vernellia R. Randall, Dying While Black 63-92 (2006); Heather K. Aeschleman, The White World of Nursing Homes: The Myriad Barriers to Access Facing Today's Elderly Minorities, 8 ELDER L.J. 367, 367-91 (2000); Ian Ayres et al., Unequal Racial Access to Kidney Transplantation, 46 VAND. L. REV. 805, 805-63 (1993); M. Gregg Bloche, Race and Discretion in American Medicine, 1 YALE J. Health POL'y L. \& Ethics 95, 95-131 (2001); René Bowser, Racial Profiling in Health Care: An Institutional Analysis of Medical Treatment Disparities, 7 Mich. J. RaCE \& L. 79, 79-133 (2001); Mark R. Bradford, An Introduction to Race as Proxy, 53 DePaul L. ReV. 929, 929-30 (2004); D. Aaron Lacy, The Most Endangered Title VII Plaintiff?: Exponential Discrimination Against Black Males, 86 NeB. L. REv. 552, 552-94 (2008); Gwendolyn Roberts Majette, Access to Health Care: What a Difference Shades of Color Make, 12 AnNALS HEalth L. 121, 123-38 (2003); Barbara A. Noah, A Prescription for Racial Equality in Medicine, 40 CONN. L. REV. 675, 683-89 (2008); Barbara A. Noah, Racial Disparities in the Delivery of Health Care, 35 SAN DIEGO L. REV. 135, 138-56 (1998); Vernellia R. Randall, Eliminating Racial Discrimination in Health Care: A Call for State Health Care Anti-Discrimination Law, 10 DePAul J. Health Care L. 1, 2-7 (2006); Vernellia R. Randall, Eliminating the Slave Health Deficit: Using Reparations to Repair Black Health, 11 POVERTY \& RACE 3, 3-8 (2002); Vernellia R. Randall, Slavery, Segregation and Racism: Trusting the Health Care System Ain't Always Easy!: An African American Perspective on Bioethics, 15 ST. LouIs U. PuB. L. ReV. 191, 193-95 (1996); Michael S. Shin, Redressing Wounds: Finding a Legal Framework to Remedy Racial Disparities in Medical Care, 90 CAL. L. Rev. 2047 (2002); Sidney D. Watson, Race, Ethnicity \& Hospital Care: The Need for Racial and Ethnic Data, $30 \mathrm{~J}$. Health \& HoSP. L. 125, 125-30 (1997); Sidney D. Watson, Race, Ethnicity and Quality Of Care:
} 
effective. Only the last point is truly controversial, particularly if the remedy is couched in the language of reparations.

In this Article, I bring my arguments forward to the present day. I wish the medical news was more positive. The statistics about Black health disparities show no improvement. The caustic history of slavery, racism, and segregation has not been undone. Fundamental changes are still necessary to repair deficits in Black health. President Barack Obama's election, however, has changed the relevance of reparations as a political tool for making these changes. We elected a Black man as President of the United States and he refuses to apply reparations talk to social programs focusing on disadvantaged community uplift. President Obama strikes broader themes, bypassing slavery reparations. More to the point, Obama's agenda holds real promise for addressing inequalities and disparities, especially in health care. At this point, perhaps Black Americans should focus on Obama's plans and let reparations rest as a political agenda.

\section{DisParities IN BLACK HEALTH IN THE AMERICAN CONTEXT}

Racial disparities in health are not a recent phenomenon. The historical record of disparity is alarmingly longitudinal:

For as long as records have been kept, studies have reported racial differences in health care access and health status in the United States.

Disparities in Black health have been studied to death, while the patients continue to die. Still more studies and reports are in the pipeline. The Tragedy of American health care is that while disparities in Black health are not new, they remain newsworthy, persisting for centuries right up to the present day.

Inequalities and Incentives, 27 AM. J.L. \& MED. 203 (2001); Ruqaiijah Yearby, Striving for Equality, But Settling for the Status Quo in Health Care: Is Title VI More Illusory Than Real?, 59 RUTGERS L. REV. 429 (2007). Additionally, several journals have published symposia on racial disparities in health. See Symposium, Disentangling Fact From Fiction: The Reality of Unequal Health Care Treatment, 9 DePaul J. Health CARE L. 1 (2005) [hereinafter Symposium, Disentangling Fact From Fiction]; Symposium, Inequalities in Health Care, 29 AM. J.L. \& MED. 151 (2003); Symposium, Unequal Treatment: Racial and Ethnic Disparities in Health Care, 48 ST. LOUIS L.J. 1 (2003).

4. Outterson, Tragedy \& Remedy, supra note 1, at 738, 740 (citations omitted). 
The statistics are grim. Black health disparities are both physical and philosophical. They are clearly dangerous to human life:

Black mortality rates are significantly higher than white rates in seven of the ten leading causes of death, resulting in more than 73,000 excess Black deaths per year. If being Black was a separate cause of death, it would rank sixth in the United States. . . B Black infant mortality in the United States is more than triple the European rate, and significantly higher than infant mortality in countries like Bulgaria, Costa Rica, Estonia, Greece, South Korea, Lithuania, and Oman, among many others. Black men's life expectancy at birth (LEAB) is currently 5.7 years less than white men's; the female disparity is 4.3 years. If a white male student were to agree to become Black, almost six years of life would be forfeited.... Even as general population health improves, most Black health disparities remain, especially for men. While gaps in health care access narrowed in the period 1968-1978, during the expansion of Medicare and Medicaid, the gaps in [LEAB] have not narrowed appreciably over the last century.... For Black men, the disparity in LEAB is even greater ... much of the gains in Black health have been among women. At current rates of change, these disparities may persist for many generations, even as absolute health improves for most groups. Nor is the situation likely to improve in the near term. For American children born in 2100, the US Census Bureau projects female LEAB to exceed 91 years for women and 87 years for men. The US Census Bureau blatantly assumes that Black LEAB will improve by 2100 , converging almost entirely with white LEAB. This assumption is made without any externally validating data. But even under this wildly optimistic and ahistorical assumption, Black ${ }_{5}$ health disparities will outlast every law professor teaching today.

Each year, the federal government collects the latest research and publishes it in the National Healthcare Disparities Report (NHDR). Each NHDR sounds some optimistic notes, but when one has read the similar reports stretching back decades, something more substantial is required for well-founded optimism. The 2007 NHDR searched in vain for evidence of consistent progress: "[t]he 2007 NHDR finds that, across all core measures and for all priority groups, the number of measures of quality and access where disparities exist grew larger between 20002001 and 2004-2005."

Some scholars approach disparities in Black health as if the problem was novel, or recently discovered. Nothing could be further from the

5. Id. at $741-44$ (citations omitted).

6. U.S. Dept. of Health \& Hum. Servs., Agency for HealthCare Res. and Quality, Key Themes and Highlights from the NAT'L HealthCARe DisParities ReP., 2007, http://www.ahrq.gov/qual/nhdr07/Key.htm (last visited Feb. 23, 2009). 
truth. Disparities in Black health are rooted in historical tragedy: the American experience of slavery, racism, Jim Crow segregation, and their legacies. ${ }^{7}$ These events were not superficial wounds to the body politic. Discrimination against Blacks has been a prominent and persistent feature of American life from the earliest days of English settlement until our present era. Slavery may be gone, but racism and legal segregation is not a phantom from the dim mists of history. We are not talking about a handful of frail veterans who faintly remember the Great War. Legal segregation was laid to rest during my lifetime and the lifetimes of more than one hundred million of my fellow citizens. This tragedy is deep and fresh, ancient and ongoing.

\section{THE ROLE OF REPARATIONS FOR BLACK HEALTH DISPARITIES}

Four years ago, I questioned whether superficial remedies would be up to the task for so grave a condition:

Any attempt to remedy health disparities cannot be limited to mere legal fictions of equality; Title VI has been ineffective in reducing disparities in Black health. Token efforts will always be confronted with the troublesome facts of 73,000 excess Black deaths per year and the continuing gap in Black life expectancies. One example of a token effort which does not affect the underlying social structures is Virginia's recently-announced plan to offer reparations for racial exclusion in education in the years following Brown v. Board of Education by offering college scholarships to the individuals (now in their 50s and 60s) who were denied access to education more than four decades ago. While apologies and scholarships are certainly appropriate, the scholarships are not nearly as useful near the end of life as they would have been at age 20. Perhaps the scholarships should be offered to the grandchildren. Better yet, everyone should receive an excellent education. Rough justice is preferable to injustice.

The Black health experience during the intervening years has not changed my opinion of the gravity of the situation. The most recent statistics do not portend a speedy end to Black health disparities. One is hard-pressed to find substantial gains since 2004. ${ }^{9}$ The long-term data are quite striking, with racial disparities surviving even major reforms such as Social Security, Medicare, Medicaid, the Civil Rights Act, the

7. Perhaps I should choose a different word. Legacies are generally understood as positive assets passed on to your descendants. Pathologies would be more descriptive here.

8. Outterson, Tragedy \& Remedy, supra note 1, at 779 (citations omitted).

9. See supra note 6 and accompanying text. 
Voting Rights Act, and SCHIP. ${ }^{10}$ Our experience over the last century suggests that even substantial reforms are not guaranteed success.

Figure 1: Life Expectancy at Birth ${ }^{11}$

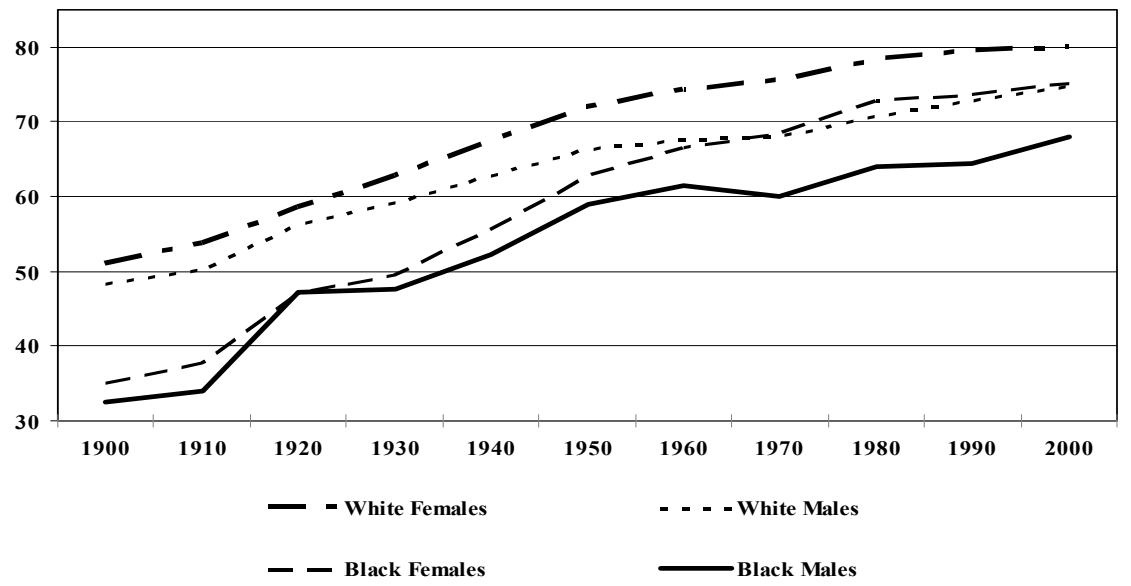

Figure 1 tells a story of vast improvements in health over the past century, but also shows persistent disparity between Black and white, male and female. The gaps on this chart represent millions of excess deaths in the twentieth century alone. Of particular note are the relatively stronger gains by Black women, whose life expectancies now exceed white men. Whatever factors have been at work, Black men most acutely felt the negative impact.

Some researchers note that the absolute gap between Black and white life expectancy has narrowed in recent decades, ${ }^{12}$ but the focus on absolute gains can be misleading. As a species, we may be reaching the top of the life expectancy curve. In the twentieth century we enjoyed unprecedented gains in U.S. life expectancy, but most experts do not expect the same in the twenty-first century. ${ }^{13}$ Medical technology and

10. See infra Figure 1.

11. Elizabeth Arias et AL., U.S. Decennial Life Tables for 1999-2001, United States Life Tables, 57 NAT'L Vital Stat. ReP. 1, 32 tbl.12 (Aug. 5, 2008), available at http://www.cdc.gov/ nchs/data/nvsr/nvsr57/nvsr57_01.pdf [hereinafter NVSR 1]; ELIZABETH ARIAS, United States Life Tables, 2004, 56 NAT'L VitAL STAT. REP. 1, 3 tbl.A (Dec. 28, 2007), available at http://www.cdc.gov/nchs/data/nvsr/nvsr56/nvsr56_09.pdf. As of February 2009, the latest available NVSR LEAB data is from 2004.

12. Sam Harper et al., Trends in the Black-White Life Expectancy Gap in the United States, 1983-2003, 297 J. AM. MED. ASs'N 1224, 1224 (2007).

13. Id. at 1229 fig.2. 
public health efforts will be hard-pressed to raise white life expectancies in the United States by another fifty percent in the next century. Matching the record of the prior century on even an absolute gain basis would still require about three decades of improvement, pushing the average human lifespan towards 120 years by the end of the twenty-first century. Figure 1 demonstrates that the rate of increase has slowed, creating statistical compression. The leading contributors to current racial disparities in health are heart disease, cancers, and infections ${ }^{14}$ the disparities are becoming particularly concentrated in the older populations. $^{15}$

If one focuses on the absolute Black-white gap in life expectancy, statistical compression could be interpreted as an optimistic note. From a different perspective, the situation is less sanguine. Consider another measure of progress: how long has it taken Black life expectancies to reach the same levels white men and women reached in previous years? For most of the past century, it has taken about a generation (27-40 years) for Black LEAB to reach white levels. ${ }^{16}$ It is hard to discern a positive trend over time in Figure 2 below.

Figure 2: Black Disparity in Life Expectancy at Birth (LEAB) ${ }^{17}$

\begin{tabular}{|l|l|l|l|}
\hline Year of Birth & \multicolumn{1}{|c|}{$\begin{array}{c}\text { Black } \\
\text { LEAB }\end{array}$} & $\begin{array}{c}\text { Year Same LEAB Was First } \\
\text { Reached by Whites }\end{array}$ & $\begin{array}{c}\text { Disparity in } \\
\text { Years }\end{array}$ \\
\hline 2004 & 73.1 & 1975 & 29 \\
\hline 2000 & 71.7 & 1970 & 30 \\
\hline 1990 & 69.1 & 1950 & 40 \\
\hline 1980 & 68.1 & 1949 & 31 \\
\hline 1970 & 64.1 & 1933 & 37 \\
\hline 1960 & 63.6 & 1933 & 27 \\
\hline 1950 & 60.8 & 1921 & 29 \\
\hline 1940 & 53.1 & 1912 & 28 \\
\hline 1930 & 48.1 & 1901 & 29 \\
\hline
\end{tabular}

14. Id. at 1227 tbl.1.

15. Id. at 1228 tbl.2.

16. See supra Figure 1.

17. See NVSR 1, supra note 11, at tbl.7; Elizabeth Arias, United States Life Tables, 2000, 51 NAT'L VitAl STAT. REP. 1, 33 tbl.12 (Dec. 19, 2002), available at http://mailer.fsu.edu / tchapin/garnet-tchapin/urp5261/exercise/US Life Tables 2000.pdf. The author analyzed data from these tables to create Figure 2. The latest available data is from 2004. See also Rashi Fein, An Economic and Social Profile of the Negro American, 94 DAEDALus 815 (1965) (providing similar time lag studies in LEAB, infant mortality rate, educational attainment, and other measures). Fein also notes that time lag studies understate the permanent disparity: "if the Negro in 1965 is where the white was in 1945, this does not mean that the Negro considers himself as well off as the white considered himself twenty years ago." Id. at 818 . 
This stagnation in Black health gains occurred despite significant Congressional attention ${ }^{18}$ and substantial funding to address racial disparities in health under the Bush Administration. We now have an annual series of National Healthcare Disparities Reports, stretching back to 2003, with mountains of supporting data. ${ }^{19}$ These efforts were not mere tokens, as in the Virginia offer of scholarships to the elderly, ${ }^{20}$ and yet they have been ineffective, at least over the short term.

Historical tragedies may call for historic remedies. Reparations offer an alternative to the status quo and incremental reforms. They hold the promise of a clean break with a shameful past and a costly catharsis before healing begins. ${ }^{21}$ But, reparations bring their own baggage and limitations, which have been widely discussed in the legal literature. ${ }^{22}$ The primary legal challenges are standing (who has the right to bring a suit on behalf of former slaves), ${ }^{23}$ statutes of limitation (everyone

18. See, e.g., William H. Frist, Overcoming Disparities in U.S. Health Care, 24

HEALTH AFF. 445 (2005) (United States Senate Majority Leader when he wrote the article); Edward M. Kennedy, The Role of the Federal Government in Eliminating Health Disparities, 24 HEALTH AFF. 452 (2005) (ranking minority member on the Senate Health, Education, Labor, and Pensions Committee when he wrote the article).

19. U.S. DeP'T of HeAlth \& Hum. SERvs., National HealthCARE Disparities Reports (AHRQ Pub. No. 08-0041), available at http://www.ahrq.gov/qual/nhdr07/nhdr07.pdf.

20. See supra text accompanying note 8 .

21. See Maxine Burkett, Reconciliation and Nonrepetition: A New Paradigm for AfricanAmerican Reparations, 86 OR. L. REV. 99 (2007) (aiming to shift the reparation discussion to one that focuses on the need for a movement centered on nonrepetition); W. Burlette Carter, True Reparations, 68 GEO. WASH. L. REV. 1021 (2000) (discussing the difficulties a politically-oriented economic reparations strategy presents); David Hall, The Spirit of Reparation, 24 B.C. THIRD WORLD L.J. 1 (2004) (exploring reparations for slavery from a spiritual perspective); Note, Bridging the Color Line: The Power of African-American Reparations to Redirect America's Future, 115 HARV. L. REV. 1689 (2002) (positing reparations not to compensate individual victims, but to repair whole communities).

22. See, e.g., Richard A. Epstein, The Case Against Black Reparations, 84 B.U. L. REV. 1177, 1178-79 (2004) (explaining the "difficulties that have dogged the various claims for black reparations"); Jack Greenberg, Reparations: Politically Inconceivable, 29 T. JEFFERSON L. REV. 157, 159 (2007) (noting that payment of reparations "comes down not to who is right, but who pays and who receives"); Saul Levmore, Changes, Anticipations, and Reparations, 99 COLUM. L. REV. 1657, 1689 (1999) ("This association of reparations with finality may in fact reflect a deeper inclination to avoid collective payments whose legal and cultural change is still very much under way."); Eric A. Posner \& Adrian Vermeule, Reparations for Slavery and Other Historical Injustices, 103 COLUM. L. REV. 689, 689 (2003) (noting that "the question of whether reparations should be paid turns crucially on choices about the form of payment, the identity of the beneficiaries, the identity" of the payers); Robert W. Tracinski, America's "Field of the Blackbirds": How the Campaign for Reparations for Slavery Perpetuates Racism, 3 J.L. SoC'Y 145, 146 (2002) (arguing reparations would "punish[] innocent people for a crime they did not commit [and] ... perpetuate racial conflict"). For my own views, see Outterson, Tragedy \& Remedy, supra note 1, at 778-85.

23. See Eric J. Miller, Representing the Race: Standing to Sue in Reparations Lawsuits, 20 HarV. Blackletter L.J. 91 (2004). See generally Outterson, Tragedy \& Remedy, supra note 1, at 781-84 (discussing the history of standing problems for reparations litigation). For discussion of reparations and class actions, see Bob Carlson, Why Slavery Reparations are Good for Civil 
involved in slavery is long dead), ${ }^{24}$ causation (linking present conditions with historical injustices), ${ }^{25}$ and sovereign immunity (many of the crimes were committed by the government, or with government sanction). ${ }^{26}$ In response, many legal theories have been proposed to address one or more of these barriers. Some writers suggest torts ${ }^{27}$ or unjust enrichment ${ }^{28}$ as possible foundations for reparation claims. Others appeal to human rights norms in international law, ${ }^{29}$ or U.S. Constitutional $\operatorname{law}^{30}$ and civil

Procedure Class, 47 ST. LouIS U. L.J. 139 (2003); Ryan Fortson, Correcting the Harms of Slavery: Collective Liability, the Limited Prospects of Success for a Class Action Suit for Slavery Reparations, and the Reconceptualization of White Racial Identity, 6 AFR.-AM. L. \& POL'Y REP. 71 (2004).

24. Suzette M. Malveaux, Statutes of Limitations: A Policy Analysis in the Context of Reparations Litigation, 74 GEO. WASH. L. REV. 68, 71 (2005) (arguing the use of the statute of limitations to bar reparations claims is against public policy). See generally Outterson, Tragedy \& Remedy, supra note 1, at 784-85 (explaining the effect of statutes of limitations on reparation litigation).

25. See, e.g., Kaimipono David Wenger, Causation and Attenuation in the Slavery Reparations Debate, 40 U.S.F. L. REV. 279, 289-90 (2006) (explaining causation arguments raised in the "reparations context" to support "a perceived lack of connection between deceased slaves and present claimants (victim attenuation), between slave beneficiaries (slave holders and governments) and modern citizens or governments (wrongdoer attenuation), and between harmful acts of slavery and any present injury (act attenuation)"). See generally Outterson, Tragedy \& Remedy, supra note 1, at 785-89 (explaining the causation challenges the "Black reparations movement [seeks to overcome by] connect[ing] modern disparities in Black health with the historical record").

26. Outterson, Tragedy \& Remedy, supra note 1, at 785.

27. See, e.g., Alfred L. Brophy, Reparations Talk: Reparations for Slavery and the Tort Law, 24 B.C. THIRD WORLD L.J. 81 (2004); Ken Cooper-Stephenson, Theoretical Underpinnings for Reparations: A Constitutional Tort Perspective, 22 WINDSOR Y.B. ACCESS JUST. 3 (2003); James R. Hackney, Jr., Ideological Conflict, African American Reparations, Tort Causation and the Case for Social Welfare Transformation, 84 B.U. L. REv. 1193 (2004). But see Keith N. Hylton, A Framework for Reparations Claims, 24 B.C. THIRD WORLD L.J. 31 (2004) (distinguishing reparation claims into two categories: social welfare and justice, and evaluating tort barriers to social welfare reparations claims).

28. See, e.g., Margalynne Armstrong, Reparations Litigation: What About Unjust Enrichment?, 81 OR. L. REV. 771 (2002); Dennis Klimchuk, Unjust Enrichment and Reparations for Slavery, 84 B.U. L. REV. 1257 (2004); Tara Kolar Ramchandani, Judicial Recognition of the Harms of Slavery: Consumer Fraud as an Alternative to Reparations Litigation, 42 HARV. C.R.-C.L. L. REV. 541 (2007); Emily Sherwin, Reparations and Unjust Enrichment, 84 B.U. L. REV. 1443 (2004).

29. See, e.g., Michael F. Blevins, Restorative Justice, Slavery, and the American Soul, A Policy-Oriented Intercultural Human Rights Approach to the Question of Reparations, $31 \mathrm{~T}$. Marshall L. ReV. 253 (2006); Max du Plessis, Reparations and International Law: How Are Reparations to be Determined (Past Wrong or Current Effects), Against Whom, and What Form Should They Take?, 22 WindSOR Y.B. ACCESS JUST. 41 (2003); Lisa Magarrell, Reparations for Massive or Widespread Human Rights Violations: Sorting Out Claims for Reparations and the Struggle for Social Justice, 22 WINDSOR Y.B. ACCESS JUST. 85 (2003); Note, World Conference Against Racism: New Avenues for Slavery Reparations?, 35 VAND. J. TRANSNAT'L L. 1235 (2002).

30. See, e.g., Yanessa L. Barnard, Better Late Than Never: A Takings Clause Solution to Reparations, 12 WASH. \& LEE J. CIV. RTS. \& SOC. JusT. 109 (2005); Daniel A. Farber, BackwardLooking Laws and Equal Protection: The Case of Black Reparations, 74 FordHAM L. REv. 2271 (2006); Edieth Y. Wu, Reparations to African-Americans: The Only Remedy for the U.S. Government's Failure to Enforce the 13th, 14th, and 15th Amendments, 3 CONN. PUB. INT. L.J. 403 
rights statutes. ${ }^{31}$ Some have focused on criminal law, ${ }^{32}$ or the record of land stolen from Blacks, ${ }^{33}$ or even the structures of inheritance law. ${ }^{34}$ Another group of scholars have turned to private defendants, including insurance companies, ${ }^{35}$ professional associations, and other corporations. $^{36}$ Saul Levmore suggests that any politically realistic reparations program must be voluntary. ${ }^{37}$ My own work uses the more recent history of health care segregation to bring the events into the 1960s and beyond, addressing some of the concerns about remoteness of injury and the statute of limitations. ${ }^{38}$ Standing issues are reduced when defendants can be clearly identified. In the health care context, many of the actors are hospitals, professional societies, and governments with legal continuity to the present day. ${ }^{39}$ Likewise, identification of a properly limited plaintiff class seems more plausible when the class is all Black Americans born in segregated hospitals or treated in segregated facilities. This class will include many millions of citizens who were born before the end of legal segregation in health care, but the class is not so vast and indeterminate as "all descendants of slaves" or "all Black Americans."

Another tact by reparations scholars has been to focus on the remedy rather than on the precise legal justification. Articles discussing

(2004).

31. See, e.g., Alfreda Robinson, Troubling "Settled" Waters: The Opportunity and Peril of African-American Reparations, 24 B.C. THIRD WORLD L.J. 139 (2004).

32. See, e.g., Eric L. Muller, Fixing a Hole: How the Criminal Law Can Bolster Reparations Theory, 47 B.C. L. REV. 659, 659 (2006).

33. See, e.g., William Darity, Jr., Forty Acres and a Mule in the [Twenty-First] Century, 89 SOC. SCI. Q. 656, 660-61 (2008).

34. See, e.g., Alfred L. Brophy, What Should Inheritance Law Be? Reparations and Intergenerational Wealth Transfers, 20 LAW \& LITERATURE 197 (2008).

35. See, e.g., Paige A. Fogarty, Speculating a Strategy: Suing Insurance Companies to Obtain Legislative Reparations for Slavery, 9 CONN. INS. L.J. 211 (2002).

36. See, e.g., Adjoa Artis Alyetoro, Truth Matters: A Call for the American Bar Association To Acknowledge Its Past and Make Reparations to African Descendants, 18 GEO. MASON U. CIV. RTS. L.J. 51 (2007) (exploring the responsibility of the ABA to provide reparations); Theodore Kornweibel, Jr., Reparations and Railroads, 29 T. JEFFERSON L. REV. 219 (2007) (discussing suing railroads); Outterson, Tragedy \& Remedy, supra note 1, at 785 (noting that private defendants such as hospitals, medical associations, and nursing homes are not protected by sovereign immunity).

37. See Saul Levmore, Privatizing Reparations, 84 B.U. L. REv. 1291, 1291 (2004) (putting forth "the unconventional idea of elective, or privatized, reparations, in which the government, through tax rules and a willingness to enforce various contingent promises, serves something of an enabling function").

38. Outterson, Tragedy \& Remedy, supra note 1, at 784-85.

39. Kevin Outterson, Slave Taxes, in Should America Pay?: Slavery and the Raging Debate on Reparations 135, 138-37 (Raymond A. Winbush ed., 2003); Outterson, Tragedy \& Remedy, supra note 1, at 781-84. 
affirmative action or education in a reparations context fall into this category, ${ }^{40}$ as does some of the health disparities literature. ${ }^{41}$

Eliminating health disparities seems an especially favorable project because the remedies are less likely to be race-specific. ${ }^{42}$ One weakness of affirmative action (in education or otherwise) is the clear racial basis for selecting winners and losers. This process has been condemned as condoning racism in the name of reparations. ${ }^{43}$ The situation for health reparations is quite different. Any structural remedy to address health disparities will likely involve systemic health reform across the board, without special preferences for patients of any particular color, ${ }^{44}$ although some Congressional legislation on racial disparities has included support for increased minority enrollment at medical schools and support for historically Black medical schools.

Randall Robinson called for a significant, multi-generational investment in Black education. ${ }^{45}$ If this program were broadened to include all children from disadvantaged backgrounds, it begins to lose its "reparational" distinctiveness, while its political prospects gain traction.

But none of this scholarship should be mistaken for broad political support for reparations. Even with Democratic majorities in the House, Representative John Conyers' bill to study reparations still has not made it out of committee. ${ }^{46}$

\section{REPARATIONS IN AN OBAMA WORLD}

Does the election of a Black man as President change the political prospects for Black reparations? Many law schools have hosted symposia on reparations, including the symposium at the University of

40. Kim Forde-Mazrui, Taking Conservatives Seriously: A Moral Justification for Affirmative Action and Reparations, 92 CAL. L. Rev. 683 (2004); David Lyons, Reparations and Equal Opportunity, 24 B.C. THIRD World L.J. 177 (2004); Harold A. McDougall, Brown at Sixty: The Case for Black Reparations, 47 How. L.J. 863 (2004); Albert Mosley, Affirmative Action as a Form of Reparations, 33 U. MEM. L. REv. 353 (2003); David J. Trevino, The Currency of Reparations: Affirmative Action in College Admissions, 4 SCHOLAR 439 (2002); see also Brief Amici Curiae of the National Coalition of Blacks for Reparations in America (N'Cobra) and the National Conference of Black Lawyers (NCBL) in Support of Respondents, Grutter v. Bollinger, 539 U.S. 306 (2003) (No. 02-241) \& Gratz v. Bollinger, 539 U.S. 244 (2003) (No. 02-516); available at http://ssrn.com/ abstract $=392060$.

41. Outterson, Tragedy \& Remedy, supra note 1, at 778-79.

42. Id. at 786 .

43. See, e.g., DAVID Horowitz, UNCIVIL WARs: The CONTROVERSY OVER REPARATIONS FOR SLAVERY (2002).

44. Id. at $787-88$.

45. Randall Robinson, The Debt: What America Owes to Blacks 244-45 (2000).

46. H. Res. 40, 111th Cong. (1st Sess. 2009). 
Kansas School of Law. In 2005, I attended one sponsored by DePaul University of Chicago, ${ }^{47}$ in conjunction with Reverend Jesse Jackson and Operation Push. We discussed health policy, racial disparities in health, and reparations. Near the end of the symposium, we sat on the stage at Operation Push while Jesse Jackson preached to the crowd of Service Employees International Union health care workers and the faithful from the South Side of Chicago. Little did we note that two blocks away future President and First Lady, Barack and Michelle Obama, were buying a home at 5046 South Greenwood Avenue. ${ }^{48}$ The contrast between Jesse Jackson and Barack Obama is striking. In his December 2007 essay in The Nation, Gary Younge discussed the rise of "new" Black politicians like Barack Obama:

The emergence of this cohort has filled the commentariat with joy-not just because of what they are: bright, polite and, where skin tone is concerned, mostly light - but because of what they are not. They have been hailed not just as a development in black American politics but as a repudiation of black American politics; not just as different from Jesse Jackson but the epitome of the anti-Jesse. ${ }^{49}$

One key difference is the rhetoric of reparations. At several points in the campaign, then-Senator Obama was asked whether he supported reparations for slavery. He deflected the question, voicing support for helping all disadvantaged schools: "if we make the investments and understand that those are our children, that's the kind of reparation [sic] that are really going to make a difference in America right now."

In other interviews, he acknowledged the reality of slavery and racism, but focused on broader remedies, avoiding some of the rhetoric of reparations:

"Asked in Moline about a controversial demand by some blacks for reparations for slavery, Obama spoke about how slavery had left a stain on the country that has yet to be eradicated. Still, he said, he opposed 'just signing checks over to African-Americans."

$$
\cdots \cdot
$$

47. Symposium, Disentangling Fact From Fiction, supra note 3.

48. Judy Keen, Tourists Flock to Obamas' Chicago Home, USA TODAY, Nov. 12, 2008, http:// www.usatoday.com/travel/destinations/2008-11-12-obama-tours_N.htm.

49. Gary Younge, The Obama Effect, THE NATION, Dec. 31, 2007, http://www.thenation.com/ doc/20071231/younge (describing the differences in the "new generation" of Black political leaders).

50. Lee Cary, Obama's Language Games, AM. THINKER, Mar. 3, 2008, http://www. americanthinker.com/2008/03/obamas_language_games.html.

51. Id. 
"The legacy of slavery is immeasurable, but the best strategies for moving forward would be vigorously enforcing our anti-discrimination laws in education and job training.",52

If Obama was giving a nuanced answer, it was lost on the press; the headlines proclaimed "Obama Opposes Slavery Reparations." "33 Obama did not contest the headline. This is unsurprising; as the first Black major party nominee for President, it was unlikely he would embrace slavery reparations. ${ }^{54}$ One reason is his path to the presidency. Most Black politicians in Congress come from majority-minority House districts. These districts are designed to have a majority of minority voters, and they reliably elect minorities to Congress. In these districts, some Representatives can champion reparations and still be re-elected every two years. As a result, the gerrymandered structure of Congressional districts creates a less centrist and potentially more radical Congressional Black Caucus. The First District of Illinois has returned Bobby Rush to Congress for eighteen years. His status as a former Black Panther has not hindered his tenure as a Congressman from the South Side of Chicago.

Obama ran against Congressman Rush in 2000 and lost. ${ }^{55}$ But, Obama polled well among white voters. These results encouraged him to subsequently run for statewide office-for the United States Senate. The political difference is immense: a statewide politician must garner a majority of the entire population, not just a majority of a racially disproportionate gerrymandered district. Obama approached the election with a different history and trajectory than traditional Black politicians. With this foundation, Obama was elected President of the United States in 2008. The rhetoric of reparations is not on his political agenda, and that fact takes it off the nation's agenda as well.

Let me be clear what my claim is here: I do not suppose that the mere election of a Black President serves in and of itself as reparation for the history of slavery, racism, and segregation. This election was full of symbolism and history, but President Obama cannot singularly carry away this debt by the simple act of election. Nevertheless, the election

52. Id.

53. Christopher Wills, Obama Opposes Slavery Reparations, The Huffington Post, Aug. 2, 2008, http://www.huffingtonpost.com/2008/08/02/obama-opposes-slavery-rep_n_116506.html.

54. Indeed, as this Article was being edited, the Obama administration counseled foreign governments against pursuing reparations claims. Colum Lynch, U.S. Holds Firm on Reparations, Israel in U.N. Racism Talks, WASH. Post, Feb. 20, 2009, at A10.

55. Janny Scott, In 2000, a Streetwise Veteran Schooled a Bold Young Obama, N.Y. TIMES, Sept. 9, 2007, http://www.nytimes.com/2007/09/09/us/politics/09obama.html. 
has permanently changed the rhetoric of reparations, even if some have not recognized it yet. If our Black President will not embrace slavery reparations, the issue will have no political traction in the United States.

And yet, fulfilling his comments on the campaign trail, President Obama may bring some of the substance of reparations without the rhetoric. As I write this Article in early 2009, he just signed a huge stimulus package. $^{56}$ The law makes historic investments in education, infrastructure, and jobs; almost unnoticed in the political debate was an additional $\$ 87$ billion for Medicaid and billions more for investment in health information technology. ${ }^{57}$ The Obama Administration is making health care reform a top priority. Major health care reform might provide near-universal coverage and make significant headway against racial disparities in health. President Obama appointed Eric Holder as U.S. Attorney General, and plans to step up enforcement of civil rights laws. But when Holder called Americans a "nation of cowards" on confronting racial issues, ${ }^{58}$ President Obama distanced himself from the remark:

I'm not somebody who believes that constantly talking about race somehow solves racial tensions . . . I think what solves racial tensions is fixing the economy, putting people to work, making sure that people have health care, ensuring that every kid is learning out there. I think if we do that, then we'll probably have more fruitful conversations.

President Obama has exiled reparations talk to the political wilderness, ignoring the impressive body of work on reparations theory. But he is talking about health care reform, education, and the needs of average Americans. If he achieves a higher quality, lower cost, and more comprehensive health care system, then Blacks will be some of the biggest beneficiaries of improved health status. He does not talk the talk, but walks the walk; avoiding reparations rhetoric in order to achieve reparational results. The end of reparations talk might be the price for actual progress in Black health.

This appears to be the deal that has been offered. I doubt a better one will become available in the next decade or two. I would celebrate

56. The American Recovery and Reinvestment Act of 2009, Pub. L. 111-5 (2009).

57. David M. Herszenhorn, A Smaller, Faster Stimulus Plan, But Still With a Lot of Money, N.Y. TIMES, Feb. 13, 2009, http://www.nytimes.com/2009/02/14/us/politics/14stimintro.ready.html.

58. Charles M. Blow, A Nation of Cowards? N.Y. TimeS, Feb. 20, 2009, http://www. nytimes.com/2009/02/21/opinion/21blow.html.

59. Helene Cooper, Attorney General Chided for Language on Race, N.Y. TIMES, Mar. 7, 2009, http://www.nytimes.com/2009/03/08/us/politics/08race.html. 
the end of Black health disparities, even if it further marginalized reparations talk. But, just like the plaintiff in the Slave Descendants Litigation, ${ }^{60}$ I lack standing to accept this deal, albeit for a different reason.

60. In re African-Am. Slave Descendants Litig., 375 F. Supp. 2d 721, $743-52$ (N.D. Ill. 2005) aff'd, 375 F. Supp. 2d 721 (7th Cir. 2006); Cato v. United States, 70 F.3d 1103, 1109 (9th Cir. 1995). 